\title{
The investigation of fetal adrenal gland sizes in the pregnancies complicated with the intrauterine growth restriction
}

\author{
Başak Kaya ${ }^{1}$ (D) , İbrahim Polat ${ }^{2}$ \\ ${ }^{1}$ Perinatology Clinic, İstanbul Medipol University, Istanbul, Turkey \\ ${ }^{2}$ Perinatology Clinic, Kanuni Sultan Siileyman Research and Training Hospital, University of Health Sciences, İstanbul, Turkey
}

\begin{abstract}
Objective: We aimed to measure fetal adrenal gland sizes in the cases of intrauterine growth restriction and to compare them with the fetuses growing consistent with the week of gestation.

Methods: Forty-four cases diagnosed with intrauterine growth restriction between 24 and 34 weeks of gestation were included in the study as the study group and 44 cases in the similar weeks of gestation and growing consistent with the week of gestation were included in the study as the control group. The fetal adrenal gland sizes of the cases were examined in the transverse sections of fetal abdomens.

Results: No significant difference was found between the study and control groups in terms of maternal age, gravida, parity, body mass index and the week of gestation during diagnosis $(p>0.05)$. The $z-$ scores of total length, total width and cortex width of the fetal adrenal glands were higher in the study group than the control group which was statistically significant $(p<0.001)$. The $z$-scores of the medulla width of the fetal adrenal glands were lower in the study group than the control group which was statistically significant $(p<0.001)$. There was no significant difference between the groups in terms of the $\mathrm{z}$-scores of the medulla length of the fetal adrenal glands $(\mathrm{p}>0.05)$.

Conclusion: It is possible to consider that the changes observed in the fetal adrenal gland sizes of the cases diagnosed with intrauterine growth restriction is a result of chronic hypoxia associated with uteroplacental failure and a component of poor fetal programming associated with the long-term poor health outcomes.
\end{abstract}

Keywords: Fetal adrenal gland, intrauterine growth restriction, hypothalamic-pituitary-adrenal axis.

\section{Özet: Fetal gelişim kısıtlılığı ile komplike gebeliklerde fetal adrenal bez boyutlarının incelenmesi}

Amaç: Fetal gelişim kısıtlılı̆̆ı olgularında fetal adrenal bez boyutlarının ölçülmesi ve gebelik haftası ile uyumlu gelişim gösteren fetüsler ile karşılaştırılması amaçlandı.

Yöntem: Gebeliğin 24-34 haftaları arasında, fetal gelişme kısıtlılığı tanısı alan 44 olgu çalışma grubu olarak ve benzer gebelik haftalarında gebelik haftası ile uyumlu gelişim gösteren 44 olgu ise kontrol grubu olarak çalışmaya dahil edildi. Olguların fetal adrenal bez boyutları fetal abdomenin transvers kesitinde incelendi.

Bulgular: Çalışma ve kontrol grupları arasında maternal yaş, gravida, parite, vücut kitle indeksi ve tanı anındaki gebelik haftası açısindan anlamlı fark saptanmadı $(\mathrm{p}>0.05)$. Fetal adrenal bez toplam uzunluğu, toplam genişliği ve korteks genişliği z-skorları çalışma grubunda kontrol grubuna göre istatistiksel olarak anlamlı şekilde yüksek saptandı $(\mathrm{p}<0.001)$. Fetal adrenal bez medulla genişliği zskoru ise çalışma grubunda kontrol grubuna göre istatistiksel olarak anlamlı şekilde düşük saptandı $(\mathrm{p}<0.001)$. Fetal adrenal bez medulla uzunluğu z-skoru açısından gruplar arasında anlamlı fark yoktu $(\mathrm{p}>0.05)$.

Sonuç: Fetal gelişim kısıtlılığı tanılı olgularda fetal adrenal bez boyutlarında gözlenen değişikliklerin uteroplasental yetmezliğe bağl1 kronik hipoksinin bir sonucu olduğu ve uzun dönem olumsuz sağlık sonuçları ile ilişkili kötü fetal programlamanın da bir bileşeni olduğu düşünülebilir.

Anahtar sözcükler: Fetal adrenal bez, fetal gelişim kısıtlılığı, hipotalamo-hipofiz-adrenal aks.

Correspondence: Başak Kaya, MD. Perinatology Clinic, İstanbul Medipol University, İstanbul, Turkey.

e-mail: kayabasak84@gmail.com / Received: December 9, 2019; Accepted: December 30, 2019

Please cite this article as: Kaya B, Polat I. The investigation of fetal adrenal gland sizes in the pregnancies complicated with the intrauterine growth restriction. Perinatal Journal 2019;27(3):176-182. doi:10.2399/prn.19.0273009 


\section{Introduction}

Fetal adrenal gland is the greatest endocrine organ in the fetal life producing mineralocorticoid, glucocorticoid and androgen beginning from the early period of fetal development. ${ }^{[1,2]}$ It is thought that the steroid hormones synthesized in the fetal adrenal gland have a regulatory role on intrauterine homeostasis, fetal organ maturation and the onset of labor. ${ }^{[3]}$ The activation of hypothalamic-pituitary-adrenal (HPA) axis is required for the synthesis of steroid hormone in the fetal adrenal gland. ${ }^{[1]}$

Intrauterine growth restriction (IUGR) is used to define the fetuses which are unable to achieve their potential growth due to fetal, placental or maternal factors. ${ }^{[4]}$ Intrauterine growth restriction due to uteroplacental failure is an important reason of perinatal morbidity and mortality. ${ }^{[5]}$ On the other hand, structural, physiological and metabolic compliance mechanisms step in as a response to uteroplacental failure and chronic hypoxia. These compliance mechanisms developing as a response to the poor intrauterine environment are associated with the long-term health problems. ${ }^{\left[{ }^{6}\right.}$

Since it was reported ${ }^{[7]}$ that intrauterine chronic fetal stress has an activating impact on the hypothalamic-pituitary-adrenal axis, our study aimed to measure fetal adrenal gland sizes in the cases of intrauterine growth restriction due to uteroplacental failure characterized with chronic hypoxia and to compare them with the fetuses growing consistent with the week of gestation.

\section{Methods}

In this cross-sectional study, 44 cases complicated with intrauterine growth restriction between 24 and 34 weeks of gestation were reviewed as the study group. Fortyfour cases whose growths were consistent with the week of gestation, did not have any additional obstetric complication, delivered at term, and at the similar weeks of gestation were reviewed as the control group. The approval of this study was obtained from the Ethics Committee of Kanuni Sultan Süleyman Research and Training Hospital of the University of Health Sciences with the decision number 2017.1.3. The informed consents of all cases were collected through the informed consent forms before including them in the study. The weeks of gestation of the cases included in the study were determined according to the first day of their last menstrual period and they were confirmed by the first trimester crown-rump length (CRL) measurement. The diagnosis of intrauterine growth restriction was established by measuring the estimated fetal weight (EFW) below the 3 rd percentile. In cases with EFW between $3 \mathrm{rd}$ and 10th percentile, the diagnosis of intrauterine growth restriction was established when the pulsatility index (PI) of umbilical artery was above 95 th percentile or the cerebroplacental rate was below 5 th percentile or the mean PI of uterine artery was above 95th percentile. ${ }^{[8]}$ The presence of multiple pregnancy, the presence of fetal structural or chromosomal anomaly, unreliable pattern of fetal heartbeat, smoking habit, the presence of morbidity accompanied by the maternal morbidity (chronic hypertension, preeclampsia, diabetes, chronic renal disease) were determined as the exclusion criteria. All fetal ultrasonographic examinations were carried by a single clinician (BK) by using Voluson 730 and Voluson E6 (GE Medical Systems, Milwaukee, WI, USA) ultrasonography devices. After the fetal anatomical examination, fetal biometry measurement, amniotic fluid measurement, and Doppler measurements of umbilical artery, middle cerebral artery, ductus venosus and uterine artery were carried out. Fetal adrenal gland was displayed on the transverse cross-section, the image was enlarged before the measurements, and total length and width of fetal adrenal gland and the length and width of medulla were measured (Figs. 1 and 2). Cortex width (the half of the difference between total width and medulla width) and the ratio of total width and medulla width was calculated. ${ }^{[9,10]}$

The clinical management of the cases was conducted independent of fetal adrenal gland measurements and without the participation of the clinician who carried out ultrasonographic measurements. The demographic and obstetric characteristics of the cases were recorded. The week of gestation during labor, birth weight, the duration between diagnosis week and delivery week, 1minute and 5-minute Apgar scores, and the hospitalization duration at the newborn intensive care unit were reviewed as perinatal outcomes.

Mean, standard deviation, median, minimum and maximum values were used as descriptive statistics. Two variables presenting compliance with the normal distribution were compared by Student's t-test. Two variables not presenting compliance with the normal distribution were compared by Mann-Whitney $U$ test. Spearman's rho correlation analysis was used to analyze the relationship between two constant variables not presenting compliance with the normal distribu- 


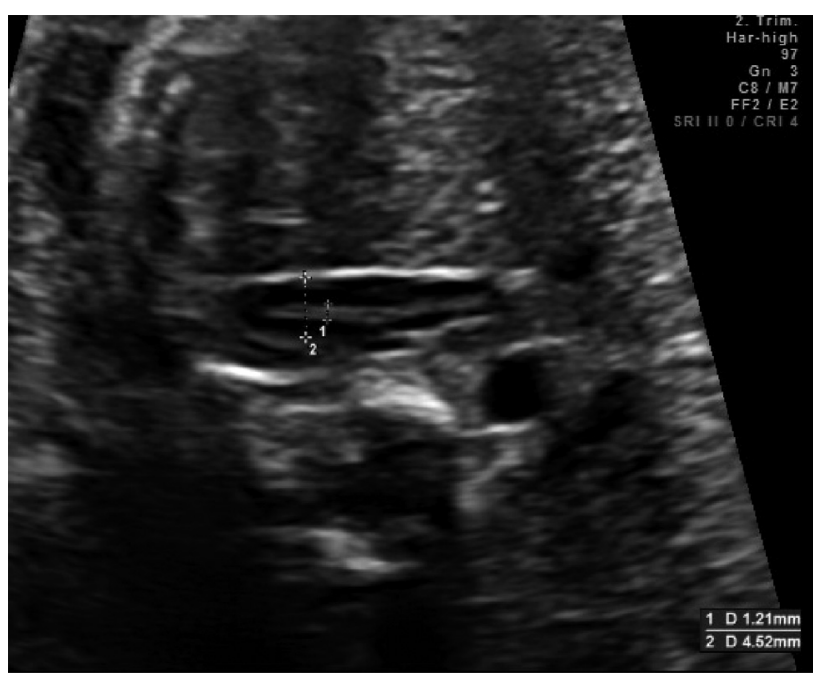

Fig. 1. Imaging fetal adrenal gland in the transverse cross-section. The medulla width (1) and total width (2) measurements of the fetal adrenal gland in the 28-week and 6-day fetus growing consistent with the week of gestation.

tion. Statistically significant level was determined 0.05 . MedCalc version 12.7.7 (MedCalc Statistical Software bvba, Ostend, Belgium) was used for the statistical analysis of the data.

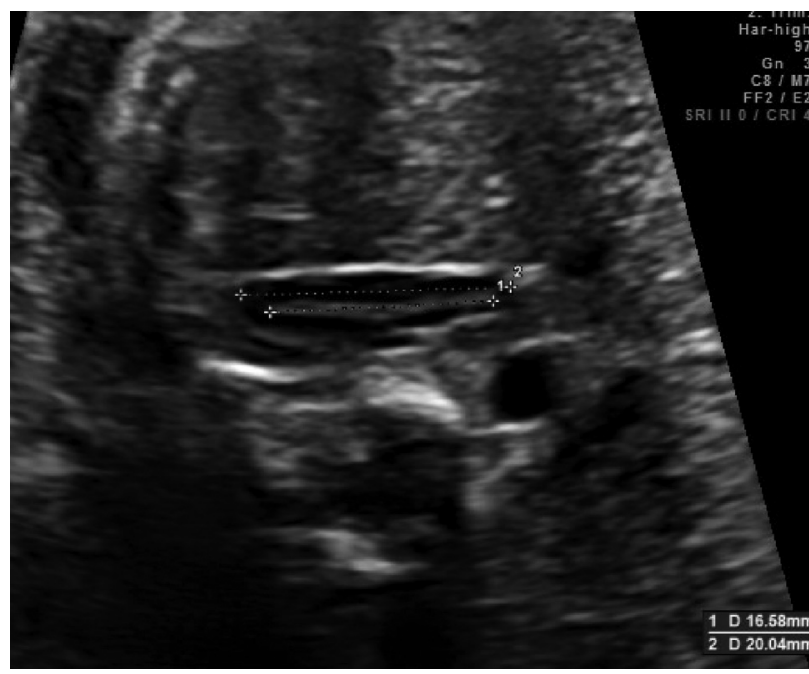

Fig. 2. Imaging fetal adrenal gland in the transverse cross-section. The medulla length (1) and total length (2) measurements of the fetal adrenal gland in the 28-week and 6-day fetus growing consistent with the week of gestation.

\section{Results}

The demographic and clinical characteristics and gestational outcomes of the cases included in the study are shown in Table 1. There was no significant difference

Table 1. Demographic and clinical characteristics and gestational outcomes of the cases.

\begin{tabular}{|c|c|c|c|}
\hline & $\begin{array}{l}\text { Intrauterine growth restriction } \\
\qquad(\mathrm{n}=44)\end{array}$ & $\begin{array}{l}\text { Control group } \\
(n=44)\end{array}$ & p-value \\
\hline \multicolumn{4}{|l|}{ Maternal characteristics } \\
\hline Year (year) & $26.8 \pm 6.1$ & $28.1 \pm 5.6$ & 0.219 \\
\hline Gravida (n) & $2(1-8)$ & $2(1-5)$ & 0.114 \\
\hline Parity (n) & $1(0-3)$ & $1(0-3)$ & 0.180 \\
\hline Body mass index $\left(\mathrm{kg} / \mathrm{m}^{2}\right)$ & $26.9 \pm 5.3$ & $26.8 \pm 3.2$ & 0.481 \\
\hline \multicolumn{4}{|l|}{ Ultrasonographic characteristics } \\
\hline Week of gestation during diagnosis (week) & $30.9 \pm 2.1$ & $30.5 \pm 2.5$ & 0.496 \\
\hline Estimated fetal weight (g) & $1284.4 \pm 358.2$ & $1641 \pm 488.6$ & $<0.001$ \\
\hline Single deepest pocket of amniotic fluid $(\mathrm{cm})$ & $3.8 \pm 0.7$ & $4.6 \pm 0.8$ & $<0.001$ \\
\hline Umbilical artery PI & $1.1 \pm 0.3$ & $0.9 \pm 0.1$ & 0.038 \\
\hline Middle cerebral artery PI & $1.7 \pm 0.4$ & $1.9 \pm 0.4$ & 0.129 \\
\hline Cerebroplacental ratio & $1.7 \pm 0.6$ & $2 \pm 0.5$ & 0.021 \\
\hline Ductus venosus PI & $0.5 \pm 0.2$ & $0.5 \pm 0.1$ & 0.789 \\
\hline Mean uterine artery PI & $1.1 \pm 0.5$ & $0.8 \pm 0.2$ & 0.016 \\
\hline \multicolumn{4}{|l|}{ Gestational outcomes } \\
\hline Week of labor (week) & $35.8 \pm 2.8$ & $38.8 \pm 0.9$ & $<0.001$ \\
\hline Period between diagnosis and labor (week) & $4.8 \pm 3$ & $8.3 \pm 2.7$ & $<0.001$ \\
\hline Birth weight (g) & $1960.1 \pm 551.3$ & $3267.3 \pm 328.9$ & $<0.001$ \\
\hline 1-minute Apgar & $9(2-9)$ & $9(6-9)$ & 0.173 \\
\hline 5-minute Apgar & $10(5-10)$ & $10(9-10)$ & 0.139 \\
\hline Hospitalization at the newborn intensive care unit (day) & $2(0-120)$ & 0 & $<0.001$ \\
\hline
\end{tabular}

PI: pulsatility index. The data are presented as mean \pm standard deviation and median (minimum-maximum). 
Table 2. Fetal adrenal gland measurements of the cases.

\begin{tabular}{|c|c|c|c|}
\hline & $\begin{array}{l}\text { Intrauterine growth restriction } \\
\qquad(\mathrm{n}=44)\end{array}$ & $\begin{array}{c}\text { Control group } \\
(n=44)\end{array}$ & p-value \\
\hline Z-score of total length & $\begin{array}{c}0.78 \\
(-1.08-2.67)\end{array}$ & $\begin{array}{c}-0.65 \\
(-1.62-0.61)\end{array}$ & $<0.001$ \\
\hline Z-score of total width & $\begin{array}{c}0.67 \\
(-1.73-2.59)\end{array}$ & $\begin{array}{c}-0.47 \\
(-1.97-0.79)\end{array}$ & $<0.001$ \\
\hline Z-score of medulla length & $\begin{array}{c}0.3 \\
(-2.21-2.06)\end{array}$ & $\begin{array}{c}-0.04 \\
(-1.58-1.81)\end{array}$ & 0.607 \\
\hline Z-score of medulla width & $\begin{array}{c}-0.52 \\
(-2.22-1.85)\end{array}$ & $\begin{array}{c}0.49 \\
(-1.2-2.86)\end{array}$ & $<0.001$ \\
\hline Z-score of cortex width & $\begin{array}{c}0.81 \\
(-0.97-2.47) \\
\end{array}$ & $\begin{array}{c}-0.73 \\
(-1.95-0.26) \\
\end{array}$ & $<0.001$ \\
\hline $\begin{array}{l}\text { Z-score of total width / } \\
\text { medulla width }\end{array}$ & $\begin{array}{c}0.61 \\
(-0.22-4.34)\end{array}$ & $\begin{array}{c}-0.81 \\
(-1.45-0.04)\end{array}$ & $<0.001$ \\
\hline
\end{tabular}

between the study and control groups in terms of maternal age, gravida, parity, body mass index and the week of gestation during diagnosis $(\mathrm{p}>0.05)$. The week of gestation during labor, the period between diagnosis and labor and birth weight were lower in the study group than the control group in a statistically significant manner $(\mathrm{p}<0.001)$. Statistically significant difference was not found between the groups in terms of 1-minute and 5minute Apgar scores ( $p>0.05)$. Fetal umbilical artery and mean uterine artery pulsatility indexes were higher in the study group in a statistically significant manner and cerebroplacental ratio was significantly lower in the study group $(\mathrm{p}<0.05)$.

The fetal adrenal gland measurements of the cases are shown in Table 2. The z-scores of fetal adrenal gland total length, total width and cortex width were higher in the study group than the control group in a statistically significant manner $(\mathrm{p}<0.001)$. The $\mathrm{z}$-score of the ratio of total width and medulla width was also significantly higher in the study group $(\mathrm{p}<0.001)$. The $\mathrm{z}$-score of fetal adrenal gland medulla width was lower in the study group than the control group in a statistically significant manner $(\mathrm{p}<0.001)$. There was no significant difference between the groups in terms of the $z$-score of fetal adrenal gland medulla length $(p>0.05)$.

When the correlation between the fetal adrenal gland measurements and the weeks of gestation was reviewed in the study group, the control group and all cases included in the study, it was seen that there was a statistically significant positive correlation between the fetal adrenal gland measurements and the weeks of gestation $(\mathrm{p}<0.001)($ Table 3$)$.

\section{Discussion}

Our study aimed to investigate the fetal adrenal gland sizes in the pregnancies complicated with intrauterine growth restriction. We hypothesized in our study that the chronic intrauterine hypoxia may cause an increase in the fetal adrenal gland sizes with the activation of hypothalamic-pituitary-adrenal axis in the presence of

Table 3. The analysis of the correlation between fetal adrenal gland measurements and the week of gestation.

\begin{tabular}{lll} 
& $\begin{array}{c}\text { All cases } \\
(\mathbf{n}=\mathbf{8 8})\end{array}$ & $\begin{array}{c}\text { Control group } \\
(\mathbf{n}=\mathbf{4 4 )}\end{array}$ \\
\hline $\begin{array}{l}\text { Z-score of } \\
\text { total length }\end{array}$ & $\mathrm{r}=.709$ & $\mathrm{r}=.932$ \\
$\mathrm{p}<.001$ & $\mathrm{p}<.001$ \\
\hline Z-score of & $\mathrm{r}=.701$ & $\mathrm{r}=.854$ \\
total width & $\mathrm{p}<.001$ & $\mathrm{p}<.001$ \\
\hline Z-score of & $\mathrm{r}=.841$ & $\mathrm{r}=.929$ \\
medulla length & $\mathrm{p}<.001$ & $\mathrm{p}<.001$ \\
\hline Z-score of & $\mathrm{r}=.542$ & $\mathrm{r}=.792$ \\
medulla width & $\mathrm{p}<.001$ & $\mathrm{p}<.001$ \\
\hline Z-score of & $\mathrm{r}=.536$ & $\mathrm{r}=.755$ \\
cortex width & $\mathrm{p}<.001$ & $\mathrm{p}<.001$ \\
\hline Z-score of total width / & $\mathrm{r}=.168$ & $\mathrm{r}=.362$ \\
medulla width & $\mathrm{p}=.118$ & $\mathrm{p}<.001$ \\
\hline
\end{tabular}

r: Spearman's rho correlation analysis. 
intrauterine growth restriction associated with placental failure. Consistently with our hypothesis, we found that the total adrenal gland length, total adrenal gland width and cortex width were significantly higher in the fetuses with intrauterine growth restriction than the fetuses growing consistent with the week of gestation.

Fetal adrenal gland is seen as an oval structure consisting of a peripheral hypoechoic field and central echogenic line in the sonography. As a result of prenatal ultrasonography and postmortem histological studies, it is considered that the peripheral hypoechogenic field is created by the adrenal cortex and the central echogenic line is created by the inner side of adrenal cortex together with the medulla. ${ }^{[11]}$ Relatively greater fetal adrenal gland sizes in the intrauterine period enables to display it on the upper pole of fetal kidneys by prenatal ultrasonography. The sensitivity of the sonographic measurements of fetal adrenal gland, which is shown to have a role on the onset of both mature and preterm labors, ${ }^{[12]}$ for the prediction of preterm labor has been investigated in many studies. ${ }^{[9,13,14]}$ Besides, the impacts of hyperinsulinemia in the presence of maternal diabetes on the function and morphology of adrenal gland have been assessed in various studies. ${ }^{[3,15]}$

The impacts of intrauterine growth restriction due to placental dysfunction on the fetal adrenal gland were investigated in the animal models. These studies found increases in the hormone synthesis of fetal adrenal gland, the weight of adrenal gland and plasma cortisol levels. ${ }^{[16,17]}$ Mohajeri et al. ${ }^{[18]}$ investigated the total adrenal gland volume and adrenal gland's fetal regional volume in the fetuses with intrauterine growth restriction, and found that the total adrenal gland volume in the fetuses with IUGR was significantly higher than the control group and adrenal gland's fetal regional volume was significantly lower than the control group. In another study investigating the adrenal gland sizes in the fetuses diagnosed with IUGR, the authors found that total adrenal gland width and cortex width was significantly higher in the group with IUGR diagnosis than the control group. ${ }^{[10]}$ Consistent with the literature, we also observed that total adrenal gland length and width and cortex width were significantly higher in the fetuses with IUGR diagnosis than the control group. In the light of current literature and the results of our study, it is possible to think that the chronic intrauterine hypoxia and chronic stress associated with the placental failure cause increases in the synthesis of fetal adrenal cortisol and fetal adrenal gland sizes by activating the hypothalamic-pituitary-adrenal axis system.

During pregnancy, fetal adrenal cortisol regulates the functioning of HHA axis by its inhibitory effect on the hypothalamic corticotropin-releasing hormone $(\mathrm{CRH}) \cdot{ }^{[1]}$ In vivo and in vitro studies showed that the cortisol produced by fetal adrenal gland induces the release of placental CRH while inhibiting the release of hypothalamic CRH. Moreover, placental CRH increased due to adrenal cortisol synthesis contributes to the production of adrenal gland cortisol. ${ }^{[2]}$ There are increasing number of evidences showing that the increased fetal glucocorticoid levels induce the maturation of the organs necessary for postnatal life while they have negative impacts on fetal development, growth and postnatal development. ${ }^{[19]}$ It can be suggested that the increased cortisol levels observed in the fetuses with IUGR diagnosis are the result of chronic hypoxia associated with placental failure, and they also contribute to the intrauterine growth restriction becoming evident due to the vicious circle they cause through the placental CRH release.

Some studies argued that directing fetal blood flow to preferably cardiac, cerebral and adrenal glands as a response to the placental failure may be another reason for the increased adrenal gland sizes in the fetuses with IUGR diagnosis. ${ }^{[18,20]}$ Observing that the greatest increases in the blood flow of chronic hypoxic sheep model are in the adrenal glands supports this hypothesis. $^{[21]}$

It is considered that the chronic hypoxia and malnourishment developing secondary to the placental failure cause poor fetal programming during the intrauterine period and lead to the long-term poor health outcomes such as metabolic syndrome, cardiovascular diseases and stroke. ${ }^{[6,22,23]}$ Similarly, it is possible to think that the increase observed in the fetal adrenal gland sizes in the presence of placental failure is an indicator of the intrauterine environmental factors affecting fetal genetic programming which leads to the long-term health outcomes.

Mohajeri et al ${ }^{[18]}$ also investigated the capacity of adrenal gland sizes in the fetuses with IUGR diagnosis 
to predict the poor perinatal outcomes. They observed that those with poorer perinatal outcomes than the fetuses with IURG diagnosis had smaller adrenal gland volume, and suggested that the sonographic examination of fetal adrenal gland at the third trimester can be used as a non-invasive method for the identification of poor perinatal outcomes in the fetuses with IUGR diagnosis. Unlike the results of this study, the authors of another study investigating the relationship between adrenal gland sizes and poor perinatal outcomes in the fetuses with IUGR diagnosis observed that there was no relationship between adrenal gland sizes and poor perinatal outcomes in the fetuses with IUGR diagnosis. ${ }^{[20]}$ Considering that the changes observed in the fetal adrenal gland sizes in the fetuses with IUGR diagnosis are the result of fetal compliance mechanisms for chronic hypoxia, it is possible to expect poor perinatal outcomes in the fetuses who cannot adapt to the negative intrauterine conditions. However, it is necessary to investigate this relationship in the further studies with higher population.

The cross-sectional design, the limited number of the population and unknown levels of fetal plasma cortisol are the limitations of our study. We investigated the adrenal gland sizes in the fetuses with intrauterine growth restriction in our study. Further studies may investigate the adrenal gland sizes of the fetuses which are small for gestational age (SGA) and compare them with the fetuses complicated with IUGR and the control group. Observing difference between the fetuses complicated with IUGR and SGA in terms of adrenal gland sizes may contribute to the differential diagnosis of these two conditions which cause difficulties for the differential diagnosis in the clinical setting.

\section{Conclusion}

It is possible to conclude that the changes that we observed in the fetal adrenal gland sizes of the fetuses diagnosed with IUGR is a result of fetal compliance mechanisms for chronic hypoxic intrauterine environment associated with uteroplacental failure and also that these changes observed are a part of the poor fetal programming leading to long-term postnatal poor health outcomes.

Conflicts of Interest: No conflicts declared.

\section{References}

1. Melau C, Nielsen JE, Frederiksen H, Kilcoyne K, Perlman S, Lundvall L, et al. Characterization of human adrenal steroidogenesis during fetal development. J Clin Endocrinol Metab 2019;104:1802-12.

2. Beshay VE, Carr BR, Rainey WE. The human fetal adrenal gland, corticotropin-releasing hormone, and parturition. Semin Reprod Med 2007;25:14-20.

3. Garcia-Flores J, Cruceyra M, Canamares M, Garicano A, Espada M, Nieto O, et al. Sonographic evaluation of fetal adrenal gland in gestational diabetes: relation to fetal growth and maternal biochemical markers. J Ultrasound Med 2017;36: 999-1007.

4. Sharma D, Shastri S, Sharma P. Intrauterine growth restriction: antenatal and postnatal aspects. Clin Med Insights Pediatr 2016;10:67-83.

5. Mendez-Figueroa H, Truong VT, Pedroza C, Khan AM, Chauhan SP. Small-for-gestational-age infants among uncomplicated pregnancies at term: a secondary analysis of 9 MaternalFetal Units Network studies. Am J Obstet Gynecol 2016;215: 628.e1-628.e7.

6. Hochberg Z, Feil R, Constancia M, Fraga M, Junien C, Carel $\mathrm{JC}$, et al. Child health, developmental plasticity, and epigenetic programming. Endocr Rev 2011;32:159-224.

7. Çorumlu E, Ulupinar E. Neurobiological effects of prenatal stress exposure. [Article in Turkish] Osmangazi Tip Dergisi 2016;38(Special Issue):89-98.

8. Figueras F, Gratacos E. Update on the diagnosis and classification of fetal growth restriction and proposal of a stagebased management protocol. Fetal Diagn Ther 2014;36:8698.

9. Hoffman MK, Turan OM, Parker CB, Wapner RJ, Wing DA, Haas DM, et al.; Nulliparous Pregnancy Outcomes Study: Monitoring Mothers-to-Be (nuMoM2b) Network. Ultrasound measurement of the fetal adrenal gland as a predictor of spontaneous preterm birth. Obstet Gynecol 2016; 127:726-34.

10. Heese S, Hammer K, Möllers M, Köster HA, Falkenberg MK, Eveslage $M$, et al. Adrenal gland size in growth restricted fetuses. J Perinat Med 2018;46:900-4.

11. Scott EM, Thomas A, McGarrigle HH, Lachelin GC. Serial adrenal ultrasonography in normal neonates. J Ultrasound Med 1990;9:279-83.

12. Liggins GC, Fairclough RJ, Grieves SA, Kendall JZ, Knox BS. The mechanism of initation of parturition in the ewe. Recent Prog Horm Res 1973;29:111-59.

13. Turan OM, Turan S, Funai EF, Buhimschi IA, Copel JA, Buhimschi CS. Fetal adrenal gland volume: a novel method to identify women at risk for impending preterm birth. Obstet Gynecol 2007;190:855-62.

14. Turan OM, Turan S, Funai EF, Buhimschi IA, Campbell CH, Bahtiyar OM, et al. Ultrasound measurement of fetal adrenal gland enlargement: an accurate predictor of preterm birth. Am J Obstet Gynecol 2011;204:311.e1-10. 
15. Hetkamp T, Hammer K, Möllers M, Köster HA, Falkenberg MK, Kerschke L, et al. Fetal adrenal gland size in gestational diabetes mellitus. J Perinat Med 2019;47:941-6.

16. Bibeau K, Battista MC, Houde V, Brochu M. Fetal adrenal gland alterations in a rat model of adverse intrauterine enviroment. Am J Physiol Regul Integr Comp Physiol 2010;298: R899-911.

17. Phillips ID, Simonetta G, Owens JA, Robinson JS, Clarke IJ, McMillen IC. Placental restriction alters the functional development of the pituitary-adrenal axis in the sheep fetus during late gestation. Pediatr Res 1996;40:861-6.

18. Farzad Mohajeri Z, Aalipour S, Sheikh M, Shafaat M, Hantoushzadeh S, Borna S, et al. Ultrasound measurement of fetal adrenal gland in fetuses with intrauterine growth restriction, an early predictive method for adverse outcome. J Matern Fetal Neonatal Med 2019;32:1485-91.

19. Ishimoto H, Jaffe RB. Development and function of the human fetal adrenal cortex: a key component in the feto-placental unit. Endocr Rev 2011;32:317-55.
20. Blue NR, Hoffman M, Allshouse AA, Grobman WA, Simhan $\mathrm{HN}$, Turan OM, et al. Antenatal fetal adrenal measurements at 22 to 30 weeks' gestation, fetal growth restriciton, and perinatal morbidity. Am J Perinatol 2019 [Epub ahead of print] doi:10.1055/s-0039-3400308

21. Poudel R, McMillen IC, Dunn SL, Zhang S, Morrison JL. Impact of chronic hypoxemia on blood flow to the brain, heart, and adrenal gland in the late-gestation IUGR sheep fetus. Am J Physiol Regul Integr Comp Physiol 2015;308: R151-62.

22. Barker DJ, Gluckman PD, Godfrey KM, Harding JE, Owens JA, Robinson JS. Fetal nutrition and cardiovascular disease in adult life. Lancet 1993;341:938-41.

23. Crispi F, Miranda J, Gratacos E. Long-term cardiovascular consequences of fetal growth restriction: biology, clinical implications, and opportunities for prevention of adult disease. Am J Obstet Gynecol 2018;218:S869-79.

Bu makalenin kullanım izni Creative Commons Attribution-NoCommercial-NoDerivs 3.0 Unported (CC BY-NC-ND3.0) lisansı aracılığılyla bedelsiz sunulmaktadir. / This work is licensed under the Creative Commons Attribution-NonCommercial-NoDerivs 3.0 Unported (CC BY-NC-ND3.0) License. To view a copy of this license, visit http://creativecommons.org/licenses/by-nc-nd/3.0/ or send a letter to Creative Commons, PO Box 1866 , Mountain View, CA 94042, USA. 